\title{
Self-made smoke formulae for an exophagic Anopheles farauti in the malaria control program in Solomon Islands
}

\author{
Toshiaki IKeshoj1 ${ }^{1)}$, Takao Kishimoto ${ }^{2)}$ and Barnard BAKoteE ${ }^{3)}$ \\ 1) Primary Health Care Promotion Program of the Japan International Cooperation \\ Agency in Solomon Islands, Honiara, Solomon Islands \\ ${ }^{2)}$ Okinawa Prefectural Institute on Public Health and Environment, \\ Ohsato, Okinawa, 901-12 Japan \\ ${ }^{3}$ Solomon Islands Medical Training and Research Institute, \\ Honiara, Solomon Islands
}

(Received: 24 June 1996; Accepted: 24 September 1996)

\begin{abstract}
Key words: smoke formulae, Anopheles farauti, malaria incidence, Solomon Islands, exophagy, pre-bednet time biting
\end{abstract}

\begin{abstract}
A persistent DDT residual spray in the past made Anopheles farauti, a major vector of malaria in Solomon Islands, exophagic and early evening biting. To cope with these adverse behaviors of mosquitos, we tested a series of self-made inexpensive smoke formulae for the entomological and epidemiological effectiveness. Mosquito candles, saw dust of $0.4 \% d$-allethrin packed in empty beer cans, repelled $75 \%$ of mosquito bites at Tenaru Mala of 127 population in Guadalcanal. Mosquito bars, the similarly treated saw dust molded in a bar shape with tapioca starch, reduced PCD malaria incidence ratios of bar users to non-users from $0.39-0.65$ to $0.06-0.14$ at Gilbert Camp of 914 population in Honiara. Fortified mosquito coils of $0.4 \% d$ allethrin also reduced malaria prevalence of 450 students from $32.7 \%$ to $8.8 \%$ at the dorms of Ruavatu Secondary School. Nightly lighting of the coils kept the new malaria incidences lower than the recovery rates. These inexpensive smoke formulae could provide an effective antimalaria measure for exophagic and pre-bednet time biting mosquitos in supplement of mosquito nets.
\end{abstract}

\section{INTRODUCTION}

The diminished effectiveness of DDT residual spray against Anopheles farauti, a major vector of malaria in Solomon Islands, was attributed to their behavioral avoidance and/or the selection of exophilic and exophagic ecotypes (Avery, 1973; Suzuki and Hirabayashi, 1995). The extensive DDT spray in Thailand was also thought for the selection of exophilic and exophagic type A of An. minimus from such endophagic, endophilic and midnight biting population as one in Assam (Somboon et al., 1995). There are many such deranged populations in $A n$. minimus, $A n$. maculatus, An. sundaicus and An. dirus in Southeast Asia (Meek, 1995). These acquired behavior of mosquitos makes insecticide-treated mosquito nets not amenable to malaria control.

To cope with this problem of $A n$. farauti, Turner (1977) tested ULV malathion spray for the control in early evenings, but without success due to the nonresidual effects of the spray, high costs and many other situational constraints. Meanwhile, Suzuki and Hirabayashi (1995) recommended villagers to wear socks for protection of their most vulnerable feet. Their compliance would, how- 
ever, be hardly expected under the tropical hot and humid conditions and in their bare foot habit. Our alternative proposal to solve the problem is outdoor lighting of the smoke formulae and protect from mosquito bites during their early evening outdoor activities. In the present work, we have formulated and tested a series of selfmade, inexpensive smoke formulae for their personal protection and reduction of malaria incidence in community.

\section{Material ANd Methods}

Three types of smoke formulae were prepared to be tested at 3 different communities.

(1) Mosquito candles. Fine saw dust was thoroughly mixed with an aqueous emulsion of $d$-allethrin at a final concentration of $0.4 \%$. After drying in shade, 20 $\mathrm{g}$ of the treated dust was loosely packed in an empty beer can of which the top had been removed and the side perforated. A small bundle of coconut husk was inserted to the center of saw dust as a candlewick. The candle burnt for 1-2 hours.

Entomological effects of the candles was tested at Tenaru Mala, Guadalcanal, a 12ha village in the middle of a large coconut plantation. The village was divided to 3 zones, Mala I, II and III consisting of 6,8 , 12 houses and 46, 48 and 79 inhabitants, respectively. Two to 4 candles were lit outdoors at each house in Mala II and III at 18:30 for 21 consecutive evenings from November 11, 1993. Although 27 permethrin-treated mosquito nets were distributed to Mala I, the village was considered as the control. Meanwhile, the effect was monitored by human bait catch, a bait person sitting outdoors away from burning candles in each zone for an hour between $18: 30$ and $19: 30$.

(2) Mosquito bars. To make easily lighted and improve villagers' compliance, saw dust mixed with various ingredients was molded in the shape of a bar. First, $550 \mathrm{~g}$ of fine saw dust was thoroughly admixed with $1 l$ of diluted glue prepared from $50 \mathrm{~g}$ of tapioca starch, $100 \mathrm{ml}$ of $6 \%$ $\mathrm{KNO}_{3}$ solution ( $1 \%$ in final concentration), $100 \mathrm{~m} l$ of $0.24 \% d$-allethrin emulsion $(0.4 \%)$ and $1 l$ of seawater $(5 \% \mathrm{NaCl})$. The kneaded dough was then pressed into a wood frame to make 12 bars at a time. Each bar measured $1.5 \times 2.5 \times 8 \mathrm{~cm}$ with a dry weight of $13 \mathrm{~g}$, which was equivalent to a commercial mosquito coil. Here, $\mathrm{KNO}_{3}$ was added for sustained burning and salts in seawater was for prolongation of burning time at a low temperature by keeping moisture.

A package of 14 bars was given to each of randomly selected 50 households of 360 villagers $(39.4 \%)$ out of 914 at Gilbert Camp, once a week from July 19 to November 28, 1994 for the first experiment, and 256 villagers (28.0\%) from February 17 to June 11,1995 for the second. They lighted 2 bars in succession outdoors for 3-4 hour from 18:30 every evening. Incidentally, the mosquito net coverage of this village was random at about $35 \%$. The epidemiological effect of the bar burning was monitored by cross referring the malaria cases filed at 8 Honiara clinics and the Central Hospital to the members of bar-given households on a computer.

(3) Fortified mosquito coils. In the later experiment, the lack of manpower for producing the above formulations forced us to utilize commercial coils, of which $0.2 \% d$-allethrin was, however, boosted to $0.4 \%$ by dipping into a $1.1 \%$ $d$-allethrin emulsion for $20 \mathrm{~min}$.

The coils were tested at 9 dorms of ca. 450 students of Ruavatu Secondary School which was located in a large coconut plantation on the seacoast $45 \mathrm{~km}$ southeast of Honiara. Seven coils were lit at each of 3 girls' dorms in the evening, first from March to May 1995 and then at all dorms from July to November. Besides the coils, all students were furnished with Olyset ${ }^{\circledR}$ (Sumika Life-Tech Co., Osaka) nets throughout the experiments. Six mass blood checks were made with Giemsa staining and malaria positive students were administered a regular regi- 
men of chloroquine.

\section{RESUlts}

1. Entomological effects of mosquito candles

The average mosquito catch decreased significantly from 44.3 of the pretreatment catch in November 9-13 to 9.6 (79\% reduction) of the post-treatment catch in November 15-December 6 at Mala II, and from 13.3 to 4.3 (68\%) at Mala III. During this period, 37.7 candles were burnt at 20 houses of the two zones (1.9 candles/house/ night) without extinction. In total, the average post-treatment catch of Mala II and III was 6.9 compared with 27.2 of the pretreatment (75\% reduction) (Fig. 1). There was a significant inverse correlation between the numbers of burnt candles and the nightly mosquito catches; the catch would have been much lower with more burnt candles. Meanwhile, the average catch at the control zone of Mala I decreased from 22.7 in November 9-13 to 3.5 in November $15-19$, which was attributed to the repellency of permethrin on the distributed mosquito nets. However, the second and third week catch of 17.7 in November 21-December 6 differed insignificantly from 22.7 in the November
9-13 period.

2. Epidemiological effects of mosquito bars

The ratio of PCD incidence of bar users to non-users at Gilbert Camp was 0.143 in August 1994, which differed significantly from 0.650 of the ratio of users to all population (360/554), and remained at the similarly low ratios of $0.107-0.172$ until the end of November when bar distribution was suspended (Fig. 2). Then, the incidence ratio increased to 0.333 and 0.224 in December and January 1995, respectively. The redistribution in the middle of February again reduced the incidence ratio to 0.072 and $0.047-0.070$ in the following months against the users' ratio of 0.389 (256/658) (In this experiment, coil users in over 70 out of 100 evenings were arbitrary considered as the users). The incidence ratio increased again to 0.276 in August and 0.161 in September responding to the termination of bar distribution.

3. Epidemiological effects of fortified mosquito coils

The prevalence dropped from $32.7 \%$ of the pretreatment in March 1995 to 20.4\%, $15.6 \%$ and $11.7 \%$ in May, August and November, respectively, by the partical use of fortified coils and the full use of permethrin-treated bednets (Fig. 3). However,

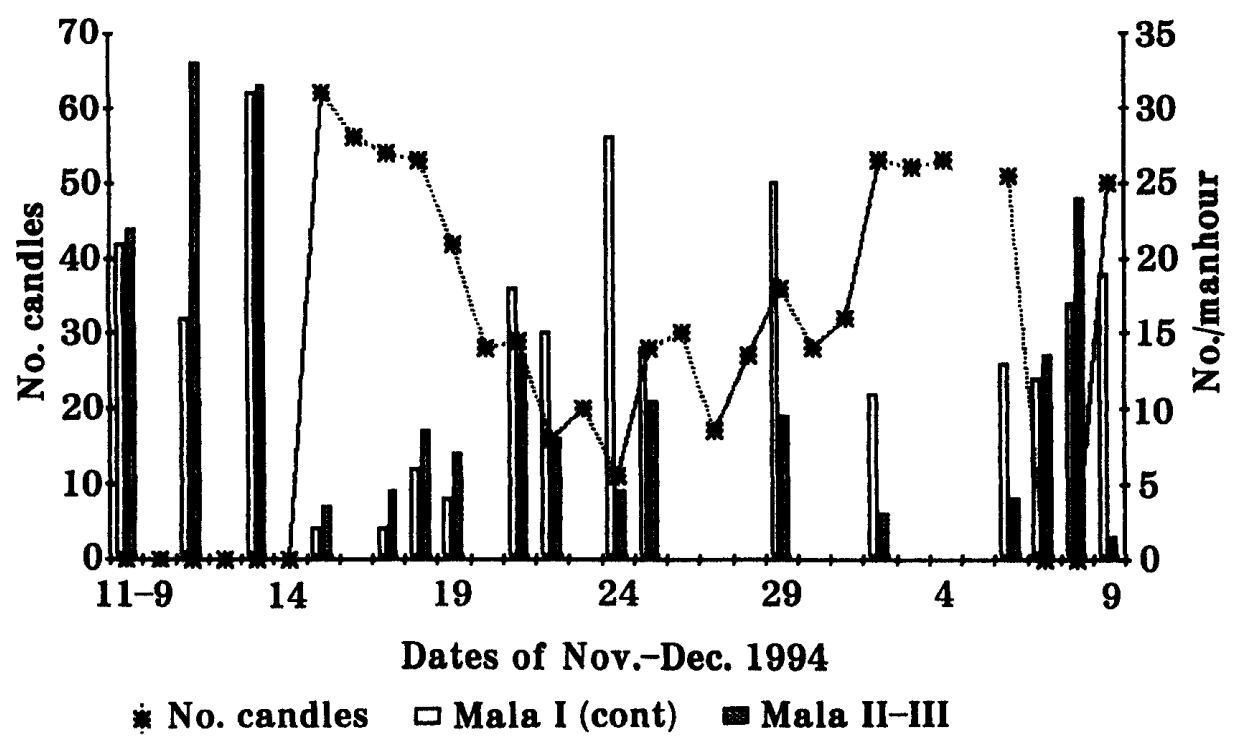

Fig. 1. Reduction of mosquito catches by human baits in lighting mosquito candles at Tenaru Mala, Guadalcanal. 


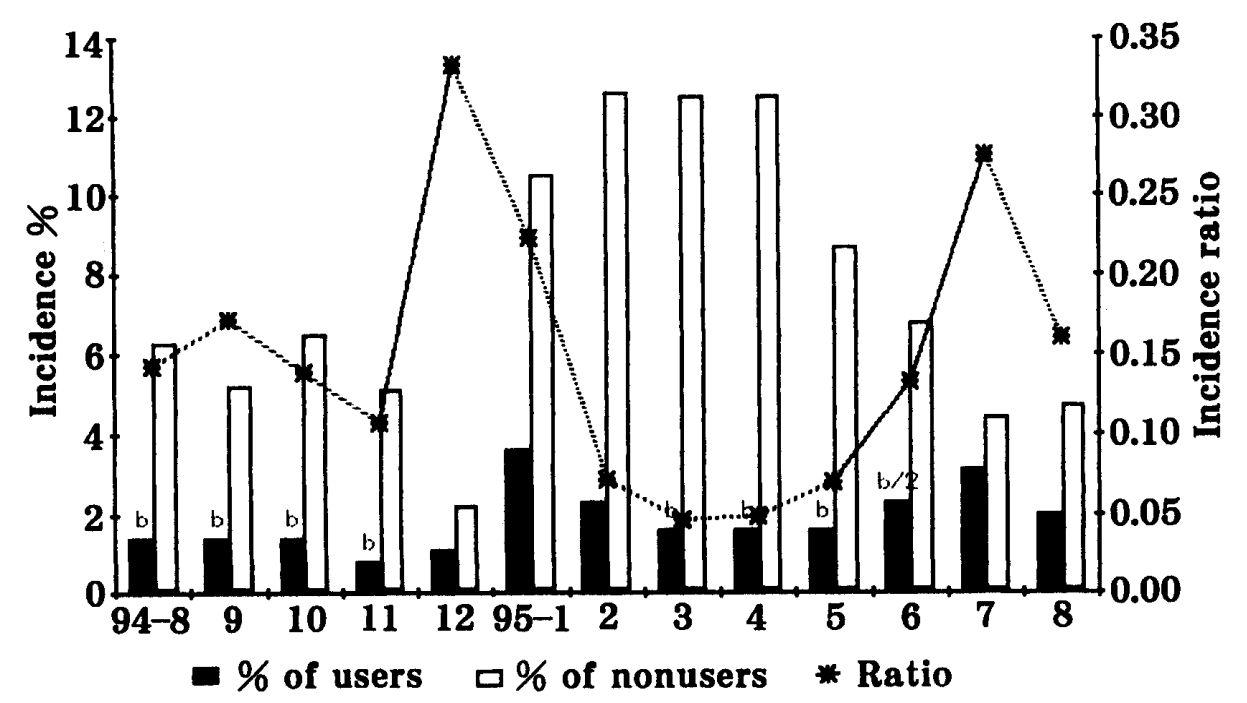

Fig. 2. Reduction of PCD malaria incidence and the ratio at Gilbert Camp, Honiara after lighting mosquito bars.

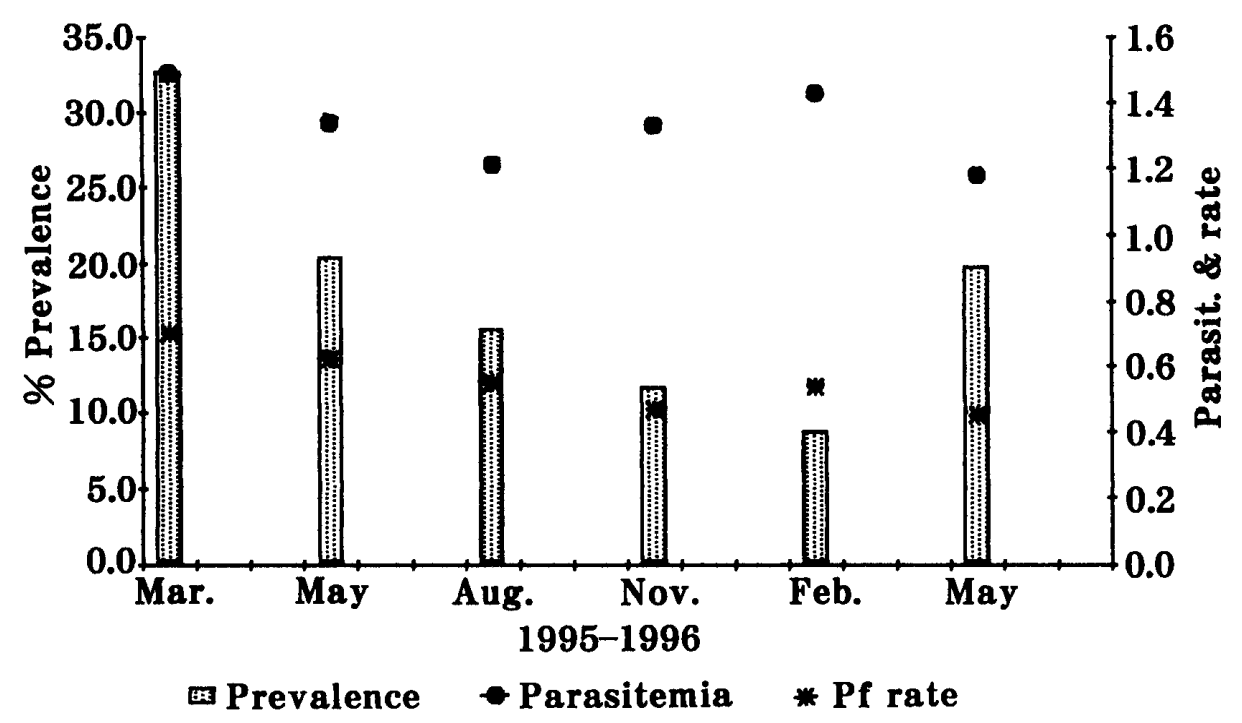

Fig. 3. Reduction of malaria prevalence and parasitemia at Ruavatu Secondary School, Guadalcanal by the integrated control.

the cessation of coil distribution doubled the prevalence from $8.8 \%$ in February 1996 to $19.8 \%$ in May. The geometrical intensity of parasitemia paralleled to the prevalence drop, but the ratio of Plasmodium falciparum to all parasites ( $P$. falciparum, vivax and ovale) did not.

The recovery of parasitemia among infected students was highest at 0.0156 after the first chloroquine administration in the period of March and May 1995, but lowest at 0.0008 by the last medication in February and May 1996 (Table 1). Meanwhile, the new incidence was always lower than the recovery rate except the last period when the incidence of 0.0014 exceeded the recovery rate of 0.0008 .

When the prevalences were t-tested by the dorms, the mean of 0.272 at pretreatment was significantly higher than 0.156 , 0.118 and 0.073 at post-treatment in August, November 1995 and February 1996, respectively (Table 2 ). In contrast, the prevalence of 0.204 in May 1995 differed insignificantly from the pretreated, because only 3 girls' dorms were treated with coils in this period. 
Table 1. Epidemiological effects of mosquito coils at Ruavatu SS.

\begin{tabular}{ccccc}
\hline \hline Period & $\begin{array}{c}\text { New } \\
\text { positive rate }\end{array}$ & $\begin{array}{c}\text { Recovery } \\
\text { rate }\end{array}$ & $\begin{array}{c}\text { New } \\
\text { incidence }\end{array}$ & $\begin{array}{c}\text { Recovery rate of } \\
\text { parasitemia }\end{array}$ \\
\hline $95.3-95.5$ & 0.120 & 0.220 & 0.0086 & 0.0156 \\
$95.5-95.8$ & 0.130 & 0.178 & 0.0049 & 0.0067 \\
$95.8-95.11$ & 0.059 & 0.100 & 0.0005 & 0.0009 \\
$96.2-96.5$ & 0.118 & 0.063 & 0.0014 & 0.0008 \\
\hline
\end{tabular}

New incidence of parasitemia; $h=(a \mid t)(a+b) \ln (1 /(1-(a+b))) a=$ new positive rate, $b=$ recovery rate, $t=$ time interval in month. Recovery rate of parasitemia; $r=(b / t)(a+b) \ln (1 /(1-(a+b)))$.

Table 2. Prevalence of malaria among Ruavatu students by the dorms.

\begin{tabular}{lcccccc}
\hline \hline Dorm & 95.3 & 95.5 & 95.8 & 95.11 & 96.2 & 96.5 \\
\hline Nilda (F) & 0.267 & 0.156 & 0.244 & 0.179 & 0.045 & 0.407 \\
LDevisi (F) & 0.255 & 0.106 & 0.148 & 0.154 & 0.133 & 0.242 \\
LLepping (F) & 0.347 & 0.224 & 0.204 & & 0.050 & 0.158 \\
Maeke (M) & 0.234 & 0.340 & 0.128 & 0.026 & 0.162 & 0.125 \\
Devisi (M) & 0.271 & 0.271 & 0.104 & 0.075 & 0.051 & 0.067 \\
SLepping (M) & 0.244 & 0.178 & 0.111 & & 0.000 & 0.375 \\
Starry (M) & 0.396 & 0.167 & 0.125 & 0.125 & 0.000 & 0.200 \\
Tovu (M) & 0.180 & 0.140 & 0.160 & 0.118 & 0.122 & 0.194 \\
Waeta (M) & 0.250 & 0.250 & 0.182 & 0.150 & 0.091 & 0.195 \\
Means & 0.272 abc & 0.204 def & 0.156 adg & 0.118 beh & $0.073 \mathrm{cfgi}$ & $0.218 \mathrm{hi}$ \\
\hline
\end{tabular}

Means with the same letters are significantly different at $5 \%$ level.

\section{Discussion}

1. Impotency of insecticide-treated mosquito nets to exophagic and exophilic species

There are ample successful research and operational applications of insecticidetreated mosquito nets made for malaria control for past $10-15$ years. At the same time, there are some works reporting and probably more not reporting unsuccessful results. One reason for the unsuccessful works is that treated mosquito nets could not reduce human-mosquito contacts because of the human outdoor activities and exophagic and exophilic behaviors of mosquitos. For instance, lambdacyhalothrintreated nets gave no apparent impact on $A n$. sawadwongporni and An. maculatus even under a high coverage because of their exophagic and zoophilic natures (Somboon et al., 1995). Alphamethrinimpregnated nets affected more an endophilic, anthropophilic species of $A n$. anthropophagus than an exophilic and zoo- philic species of $A n$. sinensis (Dapeng et al., 1994). On the contrary, An. punctulatus and $A n$. koliensis, the minor malaria vectors in Solomon Islands, were easy targets for treated-mosquito nets as they are endophilic and mid-night biting (Self, 1988), as the cases of $A n$. funestus and $A n$. gambiae s.t. in Africa.

The personal protection from bites of $A n$. farauti at their pre-bednet time is a paramount requisite. In Solomon Islands, $70-75 \%$ of mosquito bites occurs between $18: 30$ and $21: 30$. Meanwhile, 60 and $20 \%$ villagers enter houses and mosquito nets, respectively, by $20: 00$, and $95 \%$ do houses and nets by 22:00, (National Antimalaria Plan of Operation in Solomon Islands, 1993). Since the prevalence in Solomon Islands is as high as $20-40 \%$, the majority are constantly exposed to malaria transmission. Therefore, the effect of treated-mosquito nets is limited and some augumenting measures become essential for attaining a higher level of malaria control. 
2. Efficacy of the smoke formulae Mosha et al. (1992) achieved 52\% reduction in biting rates of $A n$. arabiensis and $73 \%$ of Culex quinquefasciatus with $0.15 \%$ Esbiothrin coils in Tanzania, with the favorable acceptance by the people. In the present experiments, the mosquito candle of $0.4 \% d$-allethrin showed the similar repellency of $75 \%$ to exophagic $A n$. farauti with 1.9 candles/night/house. The following mosquito bars also reduced the PCD incidence to $1 / 4$ when 2 bars were issued to a house, and to $1 / 6-1 / 9$ when the users were strictly registered. The fortified coils also reduced the prevalence among the students to $1 / 3$ when lighted 7 coils $/ 50$ students/night. In addition, the communities accepted these formulae with enthusiusm and requests for continued supplies. It is concluded that these self-made smoke formulae can either supplement or even replace permethrin-treated mosquito nets for malaria control by community participation.

3. Production costs

Sustainability and people's compliance of an effective control measure largely depends on its cost and simplicity for usage. The smoke formulae proved to effectively repel mosquitos and reduce malaira incidence, and to be produced easily with all local contents by community participation except $d$-allethrin.

According to a cost analysis (Ikeshoji, 1994), the production of two $0.4 \% d$ allethrin or permethrin mosquito bars costs only US $\$ 0.06$ and 0.02 , compared with two commercial coils of US\$ 0.133 . Lighting of these self-made formulae for 2years costs US $\$ 45.3$ and 17.5 , respectively; in comparison, an average household with 2 double and 2 single nets of 2 -year longevity requires US $\$ 26.6$ including the cost of one permethrin treatment every 6 months. Therefore, these smoke formulae are only as expensive as the permethrintreated nets. Excess permethrin after impregnation of mosquito nets at community may also be utilized for production of these smoke formulae.

\section{ACKNOWLEDGEMENT}

We acknowledge Dr. Hiroshi Omae, Japan International Medical Center for the mass blood check, Dr. Masakazu Harada and Dr. Setsuo Suguri, Department of Pathology, Kagawa University of Medicine, and the staff of Solomon Islands Medical Training and Research Institute for their help in formulation and evaluation of the smoke formulae. We are also indebted to the staff of Solomon Islands JICA/PHC project and JICA $\mathrm{HQ}$.

\section{REFERENCES}

Avery, J. G. (1973) A review of the malaria eradication programme in the British Solomon Islands, 1970-1972. Papua New Guinea Med. J., 17: 50-60.

Dapeng, L., L. Deling, Y. Renguo, L. Peng, H. Xueguang, L. Aimin, W. Lei, G. Changyin, Z. Shaowen, H. Hongru and S. Leyuan (1994) Alphamethrinimpregnated bed nets for malaria and mosquito control in China. Trans. Roy. Soc. Trop. Med. Hyg., 88: 625-628.

Ikeshoji, T. (1994) Progress Report for April 1993March 1994. Solomon Islands Primary Health Promotion Project/Japan International Cooperation Agency. p. 86.

Meek, S. R. (1995) Vector control in some countries of Southeast Asia: comparing the vectors and the strategies. Ann. Trop. Med. Parasit., 89: 135-147.

Mosha, F. W., R. J. Njau and J. Alfred (1992) Efficacy of esbiothrin mosquito coils at community level in northern Tanzania. Med. Vet. Entomol., 6: 44-46.

Self, L. S. (1989) Countries using pyrethroid impregnated mosquito nets for operational malaria control in the Western Pafcifc Region. Abstract of paper presented at 10th South-West Pacific Malaria Meeting, Honiara Solomon Islands, February 1989. p. 7.

Solomon Islands Ministry of Health and Medical Services (1993) The National Antimalaria Plan of Operation, 1994-1998. Based on Active Community Involvement. p. 45.

Somboon, P., J. Lines, A. Aramrattana, U. Chitprarop, S. Prajakwong and C. Khamboonruang (1995) Entomological evaluation of community-wide use of lamdacyhalothrin-impreganted bednets against malaria in a border area of north-west Thailand. Trans. Roy. Soc. Trop. Med. Hyg., 89: 248-254.

Suzuki, H. and K. Hirabayashi (1995) Vector mosquitos of malaria in Solomon Islands. In: Solomon 
Islands and Malaria (ed. Sasa, M., A. Ishii and N. Nihei), pp. 79-96, Nippon Nettai Igaku Kyoukai, Tokyo (in Japanese).

Turner, D. A. (1977) Ultra-low-volume ground aerosol as a supplementary anti-vector measure in the Solomon Islands malaria eradication programme. Mosq. News, 37: 624-628.

\section{摘要}

屋外吸血性蚊アノフェレス ファラウティ駆除 のための自家製蚊取線香 池庄司敏明 ${ }^{11}$ 岸本高男 ${ }^{2)}$ Barnard BAKотEE ${ }^{3)}$

1) 日本国際協力事業団専門家

（現住所：干223 横浜市港北区高田町 1236） 2) 沖縄県衛生環境研究所 （下901-12 沖縄県大里村）

3) ソロモン諸島国医学研修研究所 （ソロモン諸島国ホニアラ市）

ソロモン諸島国における主要マラリア媒介蚊アノフェ
レス ファラウティは，多年にわたる DDT 残留噴霧か ら, 屋外生息吸血性と早晚吸血性を獾得したといわれ る. 攱帳内での就寝時刻まえの最盛吸血活動を回避する ため, 住民が自作自給できる各種燻煙剤を考案し, 纹忌 避性とマラリア駆除効果について試験した. $0.4 \% d$ allethrin 含有の鋸屏を空ビール缶にいれ燃焼心をつけ た mosquito candle を, Tenaru Mala の 20 所帯で, 各 家毎夜 1.9 個を屋外点火させたところ，人四蚊捕獲数が $75 \%$ 減少した. 同材料をタピオカ㸷粉で固形化した mosquito bar を, Gilbert Camp の 120 所帯のうち 50 所帯に配布し，100 連夜点火させたところ，使用家族対 非使用家族の PCD マラリア罹患率比は, 使用前の 0.39-0.65 から0.06-0.14へ低下した。ささらに市販の $0.2 \% d$-allethrin 含有蚊取線香を再浸漬し $0.4 \%$ に強化 した線香を, Ruavatu 中高校の 9 寮生 450 人を対象に, 各尞毎夜 7 本を 9 力月間点火させたよころ, ACD マラ リア感染率は $32.6 \%$ から $8.8 \%$ へ減少した. 以上の結 果から，住民参加による生産可能で対費用効果のある， これらの雳煙剤はマラリア対策として有効であることを 宋した. 